\title{
Utilizing Technology in Arabic Teaching: Implementation of Media "Learning Aljazeera.Net" on Listening Skill Teaching at University of Darussalam Gontor
}

\author{
Siti Nikmatul Rochma \\ Universitas Darussalam (UNIDA) Gontor \\ nikmatul.rochma@unida.gontor.ac.id \\ Umi Mahmudah \\ Universitas Darussalam (UNIDA) Gontor \\ umimahmudah@unida.gontor.ac.id \\ Yuangga Kurnia Yahya \\ Universitas Darussalam (UNIDA) Gontor \\ yuangga4@unida.gontor.ac.id
}

\begin{abstract}
This research aimed to get a clear picture of the application of these media in the learning process of Arabic teaching, especially Maharab Istima' at the University of Darussalam Gontor. Learning Arabic for non-native speakers requires more variety and innovation, including in the selection of teaching materials, learning methods, and learning media. This is because learning Arabic in Indonesia is an on-going process in search for the ideal form of learning. Researchers used descriptive qualitative research methods with participatory observation data retrieval methods and documents. The researchers used Miles and Huberman's technique applied resting upon the stages of data collection, data reduction, data presentation, and drawing conclusions. The results of the study indicated that the implementation of learning.aljazeera.net media in listening session rested upon 3 main stages. They were 1) prelistening which contained vocabulary delivery, 2) the listening process which used videos from the learning.aljazeera.net website which were repeated at least 4 times, and then 3) the post-listening stage, covering the evaluation of listening activities from the simplest form to the most complex form of evaluation. The learning process of listening using the learning.aljazeera.net was a type of intensive, creative, concentrative, and explorative listening activity.
\end{abstract}

Keywords: Istima'; learning.aljazeera.net; learning media; listening 


\begin{abstract}
Abstrak
Penelitian ini bertujuan untuk mendapatkan gambaran yang jelas tentang penerapan media tersebut dalam proses pembelajaran bahasa Arab maharah istima' di Universitas Darussalam Gontor. Pembelajaran bahasa Arab bagi non penuturnya membutuhkan lebih banyak variasi dan inovasi, termasuk di dalamnya dalam pemilihan materi ajar, metode pembelajaran, dan media pembelajaran. Hal ini dikarenakan pembelajaran bahasa Arab di Indonesia masih mencari bentuk ideal pembelajarannya. Peneliti menggunakan metode penelitian kualitatif deskriptif dengan metode pengambilan data observasi partisipatif, dan dokumen. Teknik analisa yang peneliti gunakan adalah teknik Miles and Huberman, yaitu melalui tahapan pengumpulan data, reduksi data, penyajian data, dan penarikan kesimpulan. Hasil penelitian menyebutkan bahwa penerapan media Learning Aljazeera.Net pada pembelajaran menyimak melalui 3 tahapan pokok, yaitu 1) pra menyimak berisi pemberian kosa kata, 2) proses menyimak menggunakan video dari situs Aljazeera.Net yang diulang minimal 4 kali menyimak, 3) kemudian tahapan pasca menyimak yaitu evaluasi dari kegiatan menyimak dari bentuk yang paling sederhana ke bentuk evaluasi yang paling kompleks. Proses pembelajaran menyimak menggunakan situs learning aljazeera.net adalah jenis kegiatan menyimak intensif, kreatif, concentrative, dan eksploratif.
\end{abstract}

Kata kunci: Istima'; learning.aljzeera.net, media pembelajaran; menyimak.

\title{
Introduction
}

Arabic is one of the most required languages to learn in Indonesia nowadays. As English First (EF) asserts on anakui.com that Arabic has been on the top five foreign languages that has a rise number of Indonesian learners besides English, Korean, Japanese, and Mandarin ${ }^{1}$. Arabic is an official language of about 25 countries $^{2}$, widely used as well as the language of business,

1 AnakUI.com, '5 Bahasa Asing Yang Banyak Dipelajari Orang Indonesia', 2015, https://www.anakui.com/5-bahasa-asing-yang-banyak-dipelajari-orangindonesia/\#5_Bahasa_Mandarin_8220bahasa_untuk_investasi_masa_depan8221.

${ }^{2}$ M.H. Bakalla, Arabic Culture: Through Its Language and Literature (London: Keegan Paul International, Ltd., 1984); Jeffrey Bale, 'Arabic as a Heritage Language in the United States', International Multilingual Research Journal 4, no. 2 (2010): 125-51, https://doi.org/10.1080/19313152.2010.499041; Yuangga Kurnia Yahya, 'Pengaruh Penyebaran Islam Di Timur Tengah Dan Afrika Utara: Studi Geobudaya Dan Geopolitik’, Al-Tsaqafa: Jurnal Peradaban Islam 16, no. 1 (2019): 44-62. 
economics, politics, diplomacy, religion, and science. ${ }^{3}$. Hence, Arabic is one of official languages of United Nation. ${ }^{4}$

Learning Arabic for non-native Arabic learners, especially Indonesians, is driven by several orientations. Wahab concluded it into 4 orientations of Indonesian learners in learning Arabic. Those are religious, academic, professional, and economic orientations ${ }^{5}$. In terms of Arabic teaching, it is divided into 4 basic skills composed of listening skill (maharah istima), speaking skill (maharah kalam), reading skill (maharah qira'ab), and writing skill (maharah kitabab) ${ }^{6}$.

The four basic skills are integrated and used simultaneously, which means mastering a skill will improve another skills and on the contrary a lack of a skill will be obstacle in mastering the other skills. It is in line with the saying that nothing can be said before listening; nothing can be read before speaking; and nothing can be written before reading?

In the process of learning 4 basic skills of Arabic, non-native learners will find some difficulties. Hidayat divided these problems into 2 groups, linguistic problems and non-linguistic problems. Linguistic problems are the difficulties related to the grammar, meaning, and structure of the language. Meanwhile, non-linguistic problems are associated with difficulties related to the processes of learning, such as the abilities of teachers and students and the lack learning media. For instance, in the active learning process as learning of listening and speaking skills, the majority of teachers emphasized the theories instead of practicing, irrelevant and inapplicable teaching materials ${ }^{8}$. While, Dajani and friends found that some difficulties can be solved by teachers' characteristics and skills, learners' characteristics, the improvement of programs, and audio visual aids? .

3 Yuangga Kurnia Yahya, Umi Mahmudah, and Luthfi Muhyiddin, 'De-Sakralisasi Dalam Pembelajaran Bahasa Arab Di Indonesia: Analisis Bahasa Sebagai Identitas Agama’, Jurnal Lingua Applicata 3, no. 2 (2020): 57-70.

${ }^{4}$ Yahya, Mahmudah, and Muhyiddin.

5 Muhbib Abdul Wahab, 'Tantangan Dan Prospek Pendidikan Bahasa Arab Di Indonesia', Afaq Arabiyyah 2, no. 1 (2007): 1-18.

${ }^{6}$ Kamil Ramma Oensyar and Ahmad Hifni, METODOLOGI PEMBELAJARAN $B A H A S A A R A B$ (Banjarmasin: IAIN Antasari Press, 2015); Abd Wahab Rosyidi and Mamlu'atul Ni'mah, Memahami Konsep Dasar Pembelajaran Babasa Arab, 2011.

${ }^{7}$ Dihyatun Masqon, 'Al-Lughah al-'Arabiyyah: Ta'limuha Wa Ta'alumuha Fi Indonesia al-Haditsah (Qira'ah Waqi'iyyah Namudzjiatan)', TS AQAFAH 8, no. 1 (2012): 211-30.

${ }^{8}$ Nandang Sarip Hidayat, 'PROBLEMATIKA PEMBELAJARAN BAHASA ARAB', Jurnal Pemikiran Islam 37, no. 1 (2012): 82-89.

${ }^{9}$ Basma Ahmad Sedki Dajani, Salwa Mubaideen, and Fatima Mohammad Amin Omari, 'Difficulties of Learning Arabic for Non-Native Speakers', Procedia - Social and Behavioral Sciences 114 (2014): 919-26, https://doi.org/10.1016/j.sbspro.2013.12.808. 
These problems become a trigger to the teachers and researcher to improve the process of learning Arabic with various media and methods. For example, M. Khalilullah suggested strategies of learning listening skill by jigsaw, small group presentation, and gallery session ${ }^{10}$. Furthermore, some Arabic teachers offered the implementation of songs to improve listening skill ${ }^{11}$, the use audiovisual media ${ }^{12}$, the application of films ${ }^{13}$, the use of ICT ${ }^{14}$, or combining with other teaching materials, such as al-Qur'an teaching ${ }^{15}$. All these efforts are aimed to reach the effectiveness of teaching listening skill.

Based on these studies, there are various methods to improve the effectiveness of teaching Arabic listening skill. As mentioned by Mahnun ${ }^{16}$, the selection of instructional media has an important role in the process of learning. Hence, this study will complement the previous studies by offering teachers an alternative of media implementation to improve the Arabic listening skill or maharah istima'.

University of Darussalam Gontor has a vision to be the center of Qur'anic language study. The teaching of Arabic in the University of Darussalam Gontor encompasses all skills including listening, speaking, reading, and writing. It constantly makes efforts to improve the methods of teaching in order to get the most effective method of teaching, for instance, the implementation of "Learning.Aljazeera.Net" in the process of learning Arabic since odd semester of 2020-2021.

"Learning.Aljazeera.Net" is an Arabic instructional media invented by Qatar government. The media is equipped with the world news in Arabic, grammatical materials with a modern method, vocabularies enrichment, and

${ }^{10}$ M. Khalilullah, 'Strategi Pembelajaran Bahasa Arab Aktif (Kemahiran Istima' Dan Takallum)', Jurnal Sosial Budaya 8, no. 02 (2011): 219-35.

${ }^{11}$ Hasan Hasan, 'Keterampilan Mengajar Bahasa Arab Materi Istima Menggunakan

Media Lagu', Al Qalam: Jurnal Ilmiah Keagamaan Dan Kemasyarakatan 15, no. 28 (2018): 127, https://doi.org/10.35931/aq.v0i0.7.

12 Jepri Nugrawiyati, 'MEDIA AUDIO-VISUAL DALAM PEMBELAJARAN

BAHASA ARAB Pendahuluan Definisi Media Pembelajaran', El-Wasathiya: Jurnal Studi Agama 6, no. 1 (2018): 97-111.

13 Rini Rini and Renti Yasmar, 'Peningkatan Kompetensi Istima' Wa Takallum Melalui

Media Film', Arabiyatuna: Jurnal Bahasa Arab 4, no. 1 (2020): 155, https://doi.org/10.29240/jba.v4i1.1384.

${ }^{14}$ Nuril Mufidah et al., 'ICT For Arabic Learning: A Blended Learning in Istima' II', LISANUNA 8, no. 2 (2018): 174-83; Rahmat Iswanto, 'Pembelajaran Bahasa Arab Dengan Pemanfaatan Teknologi', Arabiyatuna: Jurnal Babasa Arab 1, no. 2 (2017): 139, https://doi.org/10.29240/jba.v1i2.286.

${ }^{15}$ Bayan M. Alsharbi, Omar Mubin, and Mauricio Novoa, 'Quranic Education and Technology: Reinforcement Learning System for Non-Native Arabic Children', Procedia Computer Science 184, no. 2019 (2021): 306-13, https://doi.org/10.1016/j.procs.2021.04.007.

${ }^{16}$ Nunu Mahnun, 'Media Pembelajaran (Kajian Terhadap Langkah-Langkah Pemilihan Media Dan Implementasinya Dalam Pembelajaran)', An-Nida'37, no. 1 (2012): 27-35. 
other features wrapped on the attractive animation, to provide an interesting and convenient teaching materials delivered by Arabic native speakers. Therefore, this research aims to get a clear picture of the application of these media in the learning process of Arabic listening skill (mabarah istima) at the University of Darussalam Gontor.

In this research, researchers used a descriptive qualitative research method with participatory observation data retrieval methods and documents. The object of the research was the application of the media in teaching listening skill by the lecturers. Then, researchers used Miles and Huberman's technique for data analysis, whose stages were composed of data collection, data reduction, data presentation, and drawing conclusions ${ }^{17}$.

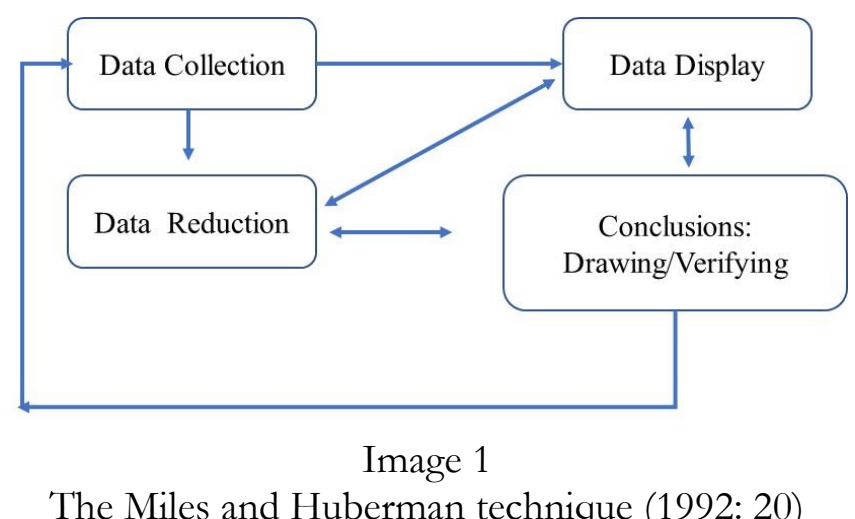

\section{Result and Discussion}

\section{Learning of Listening Skill}

Communication is a primary need of human being. The most convenient way of communication and widely used by human is verbal communication, furthermore, according to Solak and Erdem ${ }^{18}$, in the early life of human being, the communication was performed verbally by listening and speaking, and then, by time, the abilities of reading and writing came after.

Theoretically, listening means activity that involves the high concentration in order to get the information's through various media. It is also interpreted as an activity of receiving words, identifying the sound, processing and converting the messages, and then then determining the reactions to the message $^{19}$. It can be concluded that the activity of listening aims to gather

${ }_{17}$ Matthew B Miles and A Michael Huberman, Analisis Data Kualitatif: Buku Sumber Tentang Metode-Metode Baru, Terj. Tjet (Jakarta: Penerbit Universitas Indonesia, 1992).

${ }^{18}$ Ekrem Solak and Gamze Erdem, Teaching Language Skills for Prospective English Teachers, ed. Ekrem Solak (Ankara, 2016).

${ }^{19}$ Ngalimun and N Alfulaila, Pembelajaran Keterampilan Berbahasa Indonesia (Yogyakarta: 
information, data, and facts for the sake of getting inspirations and consolation through the activities of differentiating the sounds, pronunciation, accentuation of words, understanding the structure of sentences, facilitating communication, supporting speaking skills, getting inspiration, and getting entertainment.

Generally, there are 2 processes of teaching listening skill, both are bottom up process and top down process ${ }^{20}$. Due to the bottom up process, listening is a process of decoding the sounds in a linear form, from the simplest form to the most complex one ${ }^{21}$. The phonemic units being interpreted after being connected to form words, then the words arranged to form sentences, then sentences structured to form speech or meaningful script. It is a linear process which eventually leads people to get the messages. ${ }^{22}$

According to Clark and $\mathrm{Clark}^{23}$, there are several stages in listening. The first stage is identifying the smallest set of speech sounds or phoneme. The second stage is classifying the word according to the function and the context. The third stage is associating the meaning of the words in order to get the main idea. The last stage is interpreting the messages. In this last stage the listener simply focuses on the meaning of sounds.

In this process, the learner needs the vocabularies and cognition of structures of the language. There are various steps of listening practice, as identifying of word's classes, clauses, and the keyword and its transition in the paragraph, figuring out the grammatical relation among the main components of the sentences, and adapting to the pronunciations and sounds intonation in order to get the right function of the words ${ }^{24}$. It is called the conventional method of learning listening skill. Some trainings to improve it encompass some activities such as dictation, cloze listening, multiple choice after text, and etc. ${ }^{25}$

According to top-down approach, listening required the knowledge of the listener to get the message of the listening material. In other words, bottom up process is the process of understanding from language to meaning. On the contrary, the top down process is the process of understanding from meaning to

Aswaja Pressindo, 2014).

${ }^{20}$ D Nunan, 'Designing and Adapting Materials to Encourage Learner Autonomy', in Autonomy and Independence in Language Learning, ed. P Benson and P Voller (London: Longman, 1997); Jack C Richards, Teaching Listening and Speaking From Theory to Practice (Cambridge: Cambridge University Press, 2008).

${ }^{21}$ Richards, Teaching Listening and Speaking From Theory to Practice.

22 Richards.

${ }^{23}$ H.M. Clark and E.V. Clark, Psychology and Language: An Introduction to Psycholinguistics (New York: Harcourt Brace Jovanovich, 1977).

${ }^{24}$ Richards, Teaching Listening and Speaking From Theory to Practice.

${ }^{25}$ Richards. 
the language ${ }^{26}$. The required knowledge consists of discourses, contextual and conditional knowledge, and the relation among it.

In listening skill teaching, the audiolingual method is used or also called at tariqoh as sam'iyah asy syafahiyah ${ }^{27}$. This method is a method used in special learning by listening to language sounds in the form of sentences and then saying them. Another assumption of this method is that language is a habit. Therefore, a behavior will become a habit if it is repeated.

In this method, there are 3 steps in implementation. First, the teacher gives a short dialogue in Arabic which is listened to directly by the students. It is intended that students are able to identify Arabic sounds and words. Second, the teacher gives an Arabic video with the duration of about 5 to 10 minutes and asks students to understand the main idea of the video. Third, the teacher provides films with the duration of more than 10 minutes to increase students' listening skills. This method is used in special learning, where the goal is that students are able to master Arabic listening skills ${ }^{28}$.

However, the two processes of listening are harmonized each other in the real life. Both of them take turn to dominate the process depend on the listener's awareness about the topic. At one time, the top-down process can dominate the listening process. While in another time, bottom-up processes can be more important. This becomes natural, depending on whether or not a person is familiar with a topic, the content of the message, the context in which the message is delivered, and the purpose of the message ${ }^{29}$. This circumstance is closely related to the supporting factors of the learner as the books they read, the movies they watch, the music they listen, and the whole surrounding language environment ${ }^{30}$. Therefore, both of the processes are effective ways of learning listening skill.

There are several problems of non-native speaker who is learning listening skill. The most common problem is the different speed of speaking and pronunciation, the hesitation of the learner of what they heard, and memorized before, but native speakers pronounce the words they have learned in different ways ${ }^{31}$. The entire foreign language learner experienced these problems, no exception for Arabic learner.

\footnotetext{
${ }^{26}$ Richards.

27 Ahmad Fuad Effendy, Metodologi Pengajaran Bahasa Arab (Malang: Misykat, 2003).

${ }^{28}$ Effendy.

${ }^{29}$ Richards, Teaching Listening and Speaking From Theory to Practice.

30 Ömer Kutlu and Aslihan Erman Aslanoğlu, 'Factors Affecting the Listening Skill', Procedia - Social and Behavioral Sciences 1, no. 1 (2009): 2013-22, https://doi.org/10.1016/j.sbspro.2009.01.354.

${ }^{31}$ Hande Yilmaz and Fatih Yavuz, 'The Problems Young Learners Encounter During Listening Skills', Procedia - Social and Behavioral Sciences 197, no. February (2015): 2046-50, https://doi.org/10.1016/j.sbspro.2015.07.570.
} 


\section{The Stages and the Types of Listening}

Listening skill has several stages and types. According to Sudijanto ${ }^{32}$, there are 4 stages of listening. Those stages are identifying stages, identifying and selecting non retention stage, identifying with selecting in short term retention, and identifying with selecting in long term retention stage. Due to Safitri et al. ${ }^{33}$, the process of listening is divided into 5 general levels:

1. Hearing. At this basic level, the listeners catch the sounds trough the ears without any activity of interpreting to those sounds.

2. Understanding. At this level, the listeners do the activities of identifying the means of the sounds.

3. Interpreting. At this level, the listeners are able to interpret what they hear from the speaker. The process of interpretation is a continuation process from hearing to understanding processes. In the KBBI, interpreting is capturing the meaning of words not according to what they are, but also applying things that are implied or by expressing one's own opinion.

4. Evaluating. At this level, the listeners are able to capture the intention conveyed by the speaker as well as assess the advantages and disadvantages of the delivered messages, or the way it was delivered.

5. Responding. At this level, the listeners are able to respond to the things conveyed by the speaker, both verbal and non-verbal responses.

Tarigan $^{34}$ stated that there are two varieties of listening; both are the extensive listening and the intensive listening. The fundamental difference between the two lies in the extent of the purposes. The extensive listening aims to get the messages of sounds at the basic level, while the intensive listening aims to get the messages of the sounds in the higher details.

The extensive listening is commonly used in the daily life. Some of its examples are 1) social conversation listening, such as daily conversations at home, markets, stations, terminals, and listening to the radio; 2) secondary listening, which accidentally occurs such as hearing the sound of the fan, the sound of the bell, and the sound of the wind; 3) aesthetics listening or listening with the appreciative purposes as listening to music, poem, and etc.; and 4)

32 Soedjiatno Soedjiatno, Perkembangan Bahasa Jawa Sesudah Perang Dunia Kedua (Jakarta: Pusat Pembinaan dan Pengembangan Bahasa, Departemen Pendidikan dan Kebudayaan, 1984).

33 Yusmaniar Safitri, Nurzaman Nurzaman, and Tatang Tatang, 'Hubungan Antara Keterampilan Menyimak Dengan Kemampuan Menulis Karangan Bahasa Arab', Antologi.Upi.Edu, 2014, 1-9.

${ }^{34}$ Henry Guntur Tarigan, Menyimak Sebagai Suatu Keterampilan Berbahasa (Bandung: Angkasa, 2008). 
passive listening or the process capturing the sounds without purposes to understand their meanings ${ }^{35}$.

On the other hand, the intensive listening is the activity of capturing the sounds intentionally in order to get the information. There are several types of intensive listening: 1) Critical Listening, which is a process of listening which requires high concentration in order to make the listener able to evaluate objectively, determine the authenticity of the information, and identify weakness and the strengths of the content, 2) Concentrated Listening, which is a process of listening that aims to increase the ability of listener to follow certain instructions, 3) Explorative Listening, which is a process of listening that aims to gather the latest news, 4) Creative Listening, which is a process of listening that aims to develop imaginations and creativities, 5) Interrogative Listening, which means process of listening that aims to gather the facts and fresh ideas to be developed further, 6) Selective Listening, which means a process of listening aiming to raise the ability of listener to distinguish the information ${ }^{36}$.

\section{Why should use "Learning Aljazeera.Net"?}

According to Mahnun ${ }^{37}$, media is human, material, technology, tools, channel, or activities which are intentionally designed to facilitate the education process. Nowadays, in the field of foreign language learning, there had been invented various media such as e-books, audio and video devices such as video and digital broadcasts to improve the effectiveness of teaching Arabic as foreign language ${ }^{38}$, for instance Learning Aljazeera.Net. It is a media of Arabic learning initiated by a Middle East media company based in Doha, Qotar. It is used by the teachers of Arabic worldwide, so is it by the lecturers of Arabic at the University of Darussalam Gontor, Indonesia.

The implementation of 'Learning Aljazeera.Net' as the media for listening practice at University of Darussalam Gontor is based on its several excellences, For instance:

First, learning Al-Jazeera.Net contains material of Arabic learning in all levels; beginner, intermediate, and advance. Even these levels are divided into details. At the beginner level, there are 3 levels of beginner, those are at-tambidy, al-mubtadi' al-adna, and al-mubtadi' al-a'la. At the intermediate level, there are 2

35 Tarigan; I Wayan Jatiyasa, 'Pengajaran Keterampilan Menyimak Di Sekolah Dasar', Lampubyang 3, no. 2 (2012): 57-67.

${ }^{36}$ Tarigan, Menyimak Sebagai Suatu Keterampilan Berbabasa.

${ }^{37}$ Mahnun, 'Media Pembelajaran (Kajian Terhadap Langkah-Langkah Pemilihan Media Dan Implementasinya Dalam Pembelajaran)'.

38 Adam Sirajudeen and AbdulWahid Adebisi, 'Teaching Arabic as a Second Language in Nigeria', Procedia - Social and Behavioral Sciences 66 (2012): 126-35, https://doi.org/10.1016/j.sbspro.2012.11.254. 
levels of Intermediate, those are al-mutawashith al-adna and al-mutawashith al-a'la, as well 2 parts of advance level al-mutaqaddim al-adna and al-mutaqaddim al-a'la.

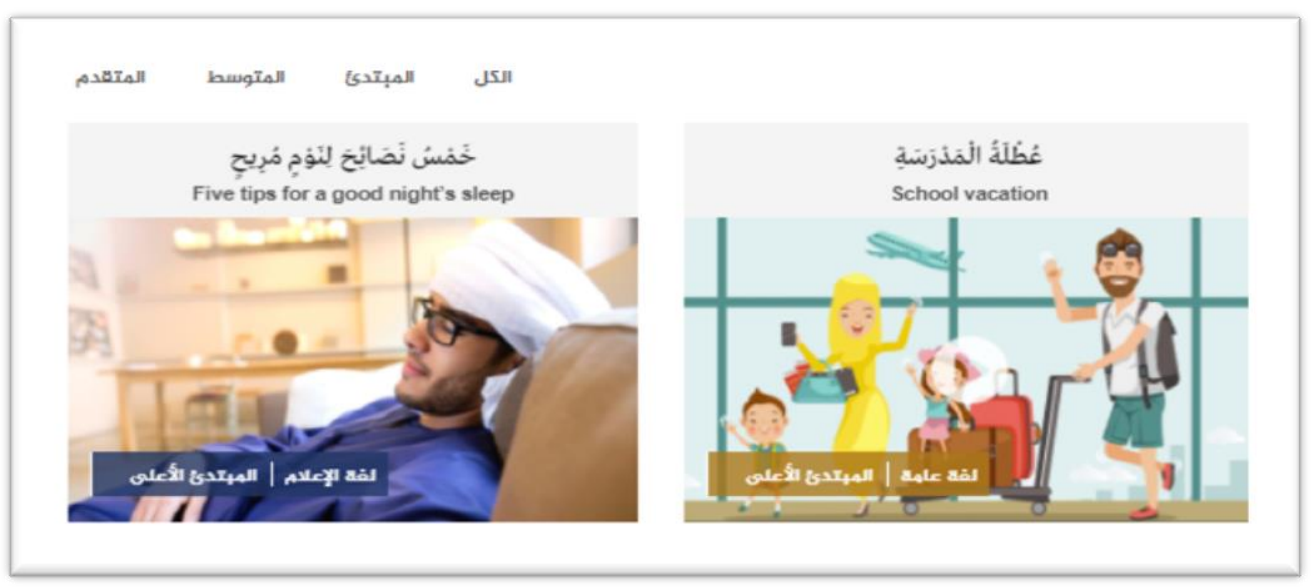

Image 2

Levels of language learning in Learning Aljazeera.Net

These variations provide teachers and students with many options. They can choose the level of learning according to their level of language ability. This option allows teachers and students to gradually improve their listening skills on an on-going basis. These variations also avoid the boredom of learning activities as they run out of materials, or learning materials that are too easy to them.

Second, the news and the conversations are delivered by Arabic native speakers. In listening to Arabic lessons, listeners must get used to listening to conversations or discourse delivery in Arabic from native speakers. This is because there are differences in the way of pronunciation and how to compose sentences as done by native speakers. Therefore, when listening directly from native speakers, the sentences delivered will be more accurate when compared to those delivered by non-native teachers because of differences in language, dialect, and so on ${ }^{39}$.

Especially in Arabic, the process of learning Arabic is often overshadowed by the emergence of interference from the basic language ${ }^{40}$. The

39 Ahmadi Ahmadi, 'Optimalisasi Pemanfaatn Laboratorium Bahasa Dalam Meningkatkan Pembelajaran Bahasa Arab', Al-Ta'rib 2, no. 1 (2014): 67-74, https://doi.org/10.23971/altarib.v2i1.1534.

40 Afif Kholisun Nashoih and M. Faridl Darmawan, 'Pengembangan Bahan Ajar Nahwu Berbasis Kontrastif Untuk Mengatasi Interferensi Bahasa Indonesia Terhadap Bahasa Arab', Arabiyatuna: Jurnal Babasa Arab 3, no. 2 (2019): 335-54, https://doi.org/10.29240/jba.v3i2.1008. 
flexive Arabic model seems less familiar to Indonesian speakers who are agglutinative. Therefore, media with native speakers is needed to stimulate the Arabic language of non-native speaker students.

Third, Learning Aljazeera.Net has diverse and varied themes and discourses of Arabic teaching materials. Generally, there are 4 types of learning materials, namely Language of Media, Daily Conversation, Arabic Literature, also Linguistic and Arabic Grammar wrapped in various interesting topics such as economy, politic, art, sport, technology, science, and general topics.

As known, there are problems in learning Arabic for Indonesian such as irrelevant material of teaching ${ }^{41}$. Media used in the process of learning was not in accordance with students' circumstance and local environmental condition ${ }^{42}$, in additions, often found media contains conversation of native speaker which does not match the cultural background of students and delivered too quickly make it difficult for novice listeners, especially the non-native learners. ${ }^{43}$

The developer of Learning Aljazeera.Net is attempting to solve the problems of Arabic teaching for non-native speaker and minimizing the gap between the native and non-native through their content. At the level of almubtadi' adna for example, the conversation themes still revolve around the selfintroduction or introducing the family members, then being increased to daily conversation around holiday, traveling, how to book apartment, conversation at migration office, and also latest news in sport, culinary, and health. In addition, all of those themes are presented in various learning features such as video, picture, short stories, short paper, and etc.

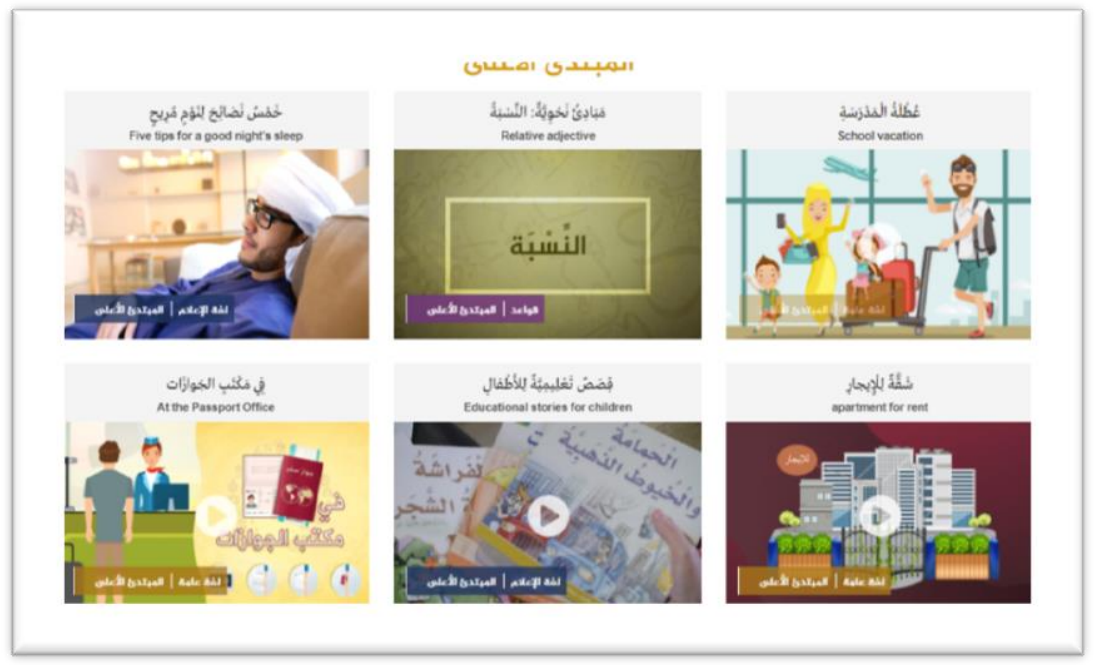

\footnotetext{
${ }^{41}$ Hidayat, 'Problematika Pembelajaran Bahasa Arab'.

42 Rosyidi and Ni'mah, Memabami Konsep Dasar Pembelajaran Babasa Arab.

${ }^{43}$ Richards, Teaching Listening and Speaking From Theory to Practice.
} 
Image 3

The chapters of teaching material in Learning.Aljazeera.Net

Fourth, Learning Aljazeera.Net is equipped by various additional features. Among the features that are useful for listening practice are the feature to hide the conversation text, also the feature to hide or show the mark (barakah) in the text, the feature to show the result after exercise, and various selections of languages. These additional features certainly help the user to improve their listening ability.

Fifth, Learning Aljazeera.Net is equipped by vocabularies and idioms according to the themes of conversation, which both of them are important in listening practice. Having vocabularies and expressions will help learners to improve their language skills ${ }^{44}$. The vocabularies and idioms provided in this website are also discussed along with their meanings in English. Indirectly, this encourages Arabic and English language skills simultaneously.

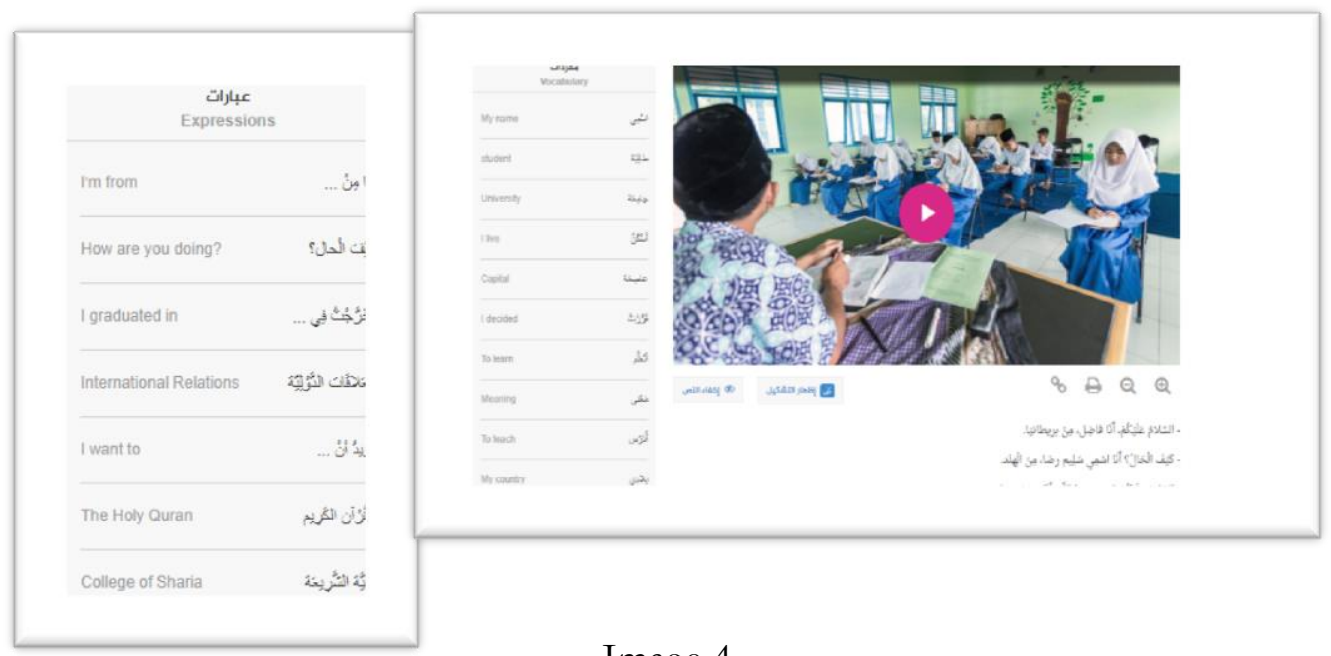

Image 4

Vocabularies and idioms attached in Learning.Aljazeera.Net

Sixth, it also has a varied learning evaluation. Evaluation is one of important parts of learning process, intended to measure the success of learning. Evaluation in language learning is divided into two forms, namely language competence and language skills. Language competence is the portrayal of

44 Widi Astuti, 'Berbagai Strategi Pembelajaran Kosa Kata Bahasa Arab', Jurnal Komunikasi Dan Pendidikan Islam 5, no. 2 (2016): 177-90; Nuril Mufidah and Intan Izha Rohima, 'Pengajaran Kosa Kata Untuk Mahasiswa Kelas Intensif Bahasa Arab', Uniqbu Journal of Social Sciences (UJSS) 1, no. 1 (2020): 13-24. 
language potential, or on the other hand, the language skill refers to ability of using language in the real act verbal or nonverbal. ${ }^{45}$

In the process of learning it will be necessary to set the goals and conducting the evaluation. In the listening process, there are at least 3 levels of learning objectives. The first goal is the ability of students to identify the words spoken by native speakers on general theme. The second goal is ability to understand conversations delivered at a moderate pace as well as expressions conveyed in speeches and news. Subsequently, the last goal as the ideal listening ability is that the students are able to understand all of the words and get the messages of conversation or news without significant difficulties.

Therefore, Learning Aljazeera.Net provides various models of learning evaluation to help teachers or lecturers conducting learning process. The evaluation form also varied, ranging from multiple choice based on the listening material, true or false statement based on the listening material, matching between sentences, essays, and so on. These models of evaluation allows teacher to conduct fun process of learning.

The six points mentioned above are the reason behind the decision of University Darussalam Gontor to use Learning Aljazeera.Net as the media of teaching Arabic listening skill for the freshman. With basic Arabic ability of the student from Pondok Modern Darussalam Gontor graduate and the equivalent institution as the absolute requirement of acceptance in University of Darussalam Gontor, it is necessary to design the Arabic learning activity to improve their language ability before going to the advance language levels in the university as the language used in the media. Without these stages, there will be a gap, between their basic language skill as freshman, with the required language skills as student of university, in other hand using this media also an act of adjustment with the model of learning in this century that going through transition from the classical method to the technology based learning ${ }^{46}$.

\section{al-Istima' Learning Stages at University of Darussalam Gontor}

University of Darussalam Gontor, through the Language Center Institute which is responsible for the development of student languages, compiles a curriculum for learning Arabic for first year students in all faculties and departments with Arabic language material consisting of learning listening skills (maharatul istima) and speaking skills (mabaratul kalam) in semester 1 and reading skills (mabaratul qira'ah) and writing skills (mabaratul kitabab) in semester

${ }^{45}$ Rosyidi and Ni'mah, Memahami Konsep Dasar Pembelajaran Babasa Arab.

46 Alasaadi Hamed, 'The Utilization of Technology in Teaching of the Arabic Language in Secondary Schools in Riyadh, Saudi Arabia', Procedia - Social and Behavioral Sciences 64 (2012): 594-603, https://doi.org/10.1016/j.sbspro.2012.11.069; Muhammad Arif Mustofa, 'Analisis Penggunaan WhatsApp Sebagai Media Pembelajaran Bahasa Arab Di Era Industri 4.0', Arabiyatuna: Jurnal Bahasa Arab 4, no. 2 (2020): 333, https://doi.org/10.29240/jba.v4i2.1805. 
2. The Language Center determines the learning.aljazeera.net site as a medium for teaching listening since the Odd semester 2020-2021 with the various considerations above. The learning process is supported by human resources in the form of lecturers who are able to actively speak fuscha Arabic.

The special learning process using this media goes through 3 stages, namely the pre-listening stage, the listening process, and the post-listening process. Each stage has a vital role in supporting the success of the learning process. In general, the use of the learning.aljazeera.net site in listening learning is as follows:

\section{Pre listening}

The teacher gives new vocabulary before starting to listen. This point is necessary because learning.aljazeera.net uses Modern Standard Arabic which has undergone many developments in meaning and structure along with the development of technology, science, and the development of political, economic, social, and other fields. The vocabulary provided comes from the vocabulary that has been provided on the page with additional vocabulary from the teacher according to the abilities of the students in the class.

The next stage is the selection of the title. Arabic teachers have the freedom to determine the title to be discussed. The titles chosen by the teacher tend to be the latest information and news such as Raf'u-l-aadzan fii Almaaniyaa li muwaajahati corona, Qithah Ayaa Shofia, Maa qishotubaa?, As siyaakhah bil manarilil-mutkharrikah, Hal takhtafidzu al-kalimatu bii ma' naahaa 'abara zaman? with the condition that the average video duration is $2-3$ minutes.

The titles are taken from the General Language and Language of Media groups at the intermediate level. This selection is based on the consideration that the majority of first year students at University of Darussalam Gontor are graduates of Darussalam Gontor Modern Boarding School or similar institutions who already have basic Arabic language skills such as most Islamic boarding school or pesantren in Indonesia which taught Arabic ${ }^{47}$. The approach used in this case is a top-down approach, where students are given vocabulary or keywords first to become capital to understand the content to be listened to.

If necessary, the teacher provides an overview or brief introduction (muqaddimah) about the material to be listened to. This introduction has an important role to provide a little overview of the theme that will be raised, the title of the video that will be watched, and the context of the conversation that will occur. With this brief explanation, it is hoped that it will make it easier for

\footnotetext{
47 Ismail Suardi Wekke, 'Arabic Teaching and Learning: A Model from Indonesian Muslim Minority', Procedia - Social and Behavioral Sciences 191 (2015): 286-90, https://doi.org/10.1016/j.sbspro.2015.04.236.
} 
students to understand new things that will be encountered during the listening process.

\section{Listening process}

This stage is the core stage in the learning process. In this stage, there are at least 3 things that need to be done. First, the teacher plays the video for the first time or the hearing stage. Listening students are assisted with some new vocabularies that have been given and videos that visualize the content of the news, connecting every word, sentence, and utterance, so that they arrive at an overview of the news content.

In the first listening stage, in general, students have not been able to capture the contents of the video content in detail. This is due to the difference between the dialect of Arabic speakers and the Arabic dialect that is heard every day at the University of Darussalam Gontor. Among them is the mention of the letters أ. In addition, the speed of speech by native Arabic speakers is different from Indonesian Arabic learners who tend to be clear and slow in pronouncing Arabic letters. This causes at this stage, the listening process that is carried out is to identify the sound that is heard and the effort to stick the meaning in each word that is heard. Theoretically, this stage is the second listening stage or the stage of identification and selection without retention (without criticizing, remembering, and reproducing).

Second, the teacher plays the video the second and third times. At this stage, students begin to interpret in more detail the contents of the content they hear. After the second and third video playback, students have reached the third listening stage, namely the identification and short-term retention stage. When students were asked about the content in general, they could not fully answer it. They are able to mention some things in the form of pieces of information only, but have not been able to reproduce it in the form of a complete information discourse.

Third, teacher plays the video for the fourth time. In this phase, most students have reached the fourth stage in listening, which is the identification and long-term retention stage. At this stage, students begin to be able to reproduce news content as complete information. The teacher will randomly ask students to interpret the things they have understood in the information in the video they have watched before.

\section{Post listening}

Post-listening activities are evaluation activities to see and measure the level of success in listening. In this stage, the teacher gives several assignments as a tool to measure students understanding of the learning process that has taken place. The evaluation activities carried out can be classified as follows: 
a. Doing questions on the learning.aljazeera.net site from the easiest form of questions such as determining which statements are true and false according to the video content, choosing the right answer from the questions given by the teacher in the form of multiple choice questions, connecting 2 relevant statements, and so on . The evaluation results can be seen directly through the special features available on the page.

b. The next level of evaluation is asking students to make conclusions. These conclusions are drawn from the content of news, information, or conversations that they have listened to and produce it in their own overall style of language. This stage is carried out to stimulate students in using the expressions (idioms) and vocabulary they get in the media appropriately.

c. The next stage is to provide feedback about the content of the video. At this stage, students are asked to give a short response to the video they have watched in front of their friends. Furthermore, there will be discussions between students both in the form of groups and as a whole to all class members.

In this stage, students are required to use their language skills by producing the vocabulary they captured in the video. After that, they will try to assemble the ideas contained in the entire content of the video and express them using the vocabulary and idioms they are good at. This is what makes maharah more complex than reading skills ${ }^{48}$.

From the explanation above, it can be seen from the listening learning process using the learning.aljazeera.net site at Darussalam Gontor University, which is a type of listening learning:

a. Intensive and creative which include critical listening activities that aim to understand and provide an assessment or response about the content of the video, namely the post-listening stage with orders to conclude and provide feedback about the content of the video.

b. concentrated namely listening by focusing on getting a good understanding of the content of the video because the listening learning model is a direct listening model in the classroom.

c. exploratory namely listening to get new information.

This learning model also adopts 5 levels of listening, which contains hearing, understanding, interpreting, evaluating, and responding. This model also fulfills 3 levels of listening objectives, namely understanding light conversation, medium conversation, and high one which is carried out in stages and can be measured by looking at the results of the evaluation of the learning process.

\footnotetext{
${ }^{48}$ Salim Abu Rabia, 'The Role of Short Vowels in Arabic Listening Comprehension', Journal of Psycholinguistic Research 48, no. 3 (2019): 699-712, https://doi.org/10.1007/s10936-018-09626-7.
} 


\section{Conclusion}

Learning Arabic in Indonesia has many challenges and problems. Therefore, it is necessary to look for various media to help teachers and students to get maximum results in learning. The application of Media "Learning.Aljazeera.Net" in learning Arabic listening skill (istima) at University of Darussalam Gontor is one of them. This learning process uses learning.aljazeera.net media with various considerations of the advantages of this media in fulfilling language needs, that contain general conversational language, media language, and literary language. This learning process goes through 3 main stages, those are pre-listening which contains vocabulary delivering and short introduction, the process of listening to videos, and post-listening stages, which contains the evaluation of listening activities from the simplest form to the most complex form of evaluation. This learning model is still in the testing phase. Therefore, it is necessary to conduct further research on the effectiveness in its application as well as the development of Istima' teaching materials at University of Darussalam Gontor in particular.

\section{Bibliography}

Abu Rabia, Salim. 'The Role of Short Vowels in Arabic Listening Comprehension'. Journal of Psycholinguistic Research 48, no. 3 (2019): 699712. https://doi.org/10.1007/s10936-018-09626-7.

Ahmadi, Ahmadi. 'Optimalisasi Pemanfaatn Laboratorium Bahasa Dalam Meningkatkan Pembelajaran Bahasa Arab'. Al-Ta'rib 2, no. 1 (2014): 6774. https://doi.org/10.23971/altarib.v2i1.1534.

Alsharbi, Bayan M., Omar Mubin, and Mauricio Novoa. 'Quranic Education and Technology: Reinforcement Learning System for Non-Native Arabic Children'. Procedia Computer Science 184, no. 2019 (2021): 306-13. https://doi.org/10.1016/j.procs.2021.04.007.

AnakUI.com. '5 Bahasa Asing Yang Banyak Dipelajari Orang Indonesia', 2015. https://www.anakui.com/5-bahasa-asing-yang-banyak-dipelajari-orangindonesia/\#5_Bahasa_Mandarin_8220bahasa_untuk_investasi_masa_de pan8221.

Astuti, Widi. 'Berbagai Strategi Pembelajaran Kosa Kata Bahasa Arab'. Jurnal Komunikasi Dan Pendidikan Islam 5, no. 2 (2016): 177-90.

Bakalla, M.H. Arabic Culture: Through Its Language and Literature. London: Keegan Paul International, Ltd., 1984.

Bale, Jeffrey. 'Arabic as a Heritage Language in the United States'. International Multilingual Research Journal 4, no. 2 (2010): 125-51. https://doi.org/10.1080/19313152.2010.499041. 
Clark, H.M., and E.V. Clark. Psychology and Language: An Introduction to Psycholinguistics. New York: Harcourt Brace Jovanovich, 1977.

Dajani, Basma Ahmad Sedki, Salwa Mubaideen, and Fatima Mohammad Amin Omari. 'Difficulties of Learning Arabic for Non-Native Speakers'. Procedia - Social and Behavioral Sciences 114 (2014): 919-26. https://doi.org/10.1016/j.sbspro.2013.12.808.

Effendy, Ahmad Fuad. Metodologi Pengajaran Bahasa Arab. Malang: Misykat, 2003.

Hamed, Alasaadi. 'The Utilization of Technology in Teaching of the Arabic Language in Secondary Schools in Riyadh, Saudi Arabia'. Procedia - Social and Behavioral Sciences 64 (2012): 594-603. https://doi.org/10.1016/j.sbspro.2012.11.069.

Hasan, Hasan. 'Keterampilan Mengajar Bahasa Arab Materi Istima Menggunakan Media Lagu'. Al Qalam: Jurnal Ilmiah Keagamaan Dan Kemasyarakatan 15, no. 28 (2018): 127. https://doi.org/10.35931/aq.v0i0.7.

Hidayat, Nandang Sarip. 'PROBLEMATIKA PEMBELAJARAN BAHASA ARAB'. Jurnal Pemikiran Islam 37, no. 1 (2012): 82-89.

Iswanto, Rahmat. 'Pembelajaran Bahasa Arab Dengan Pemanfaatan Teknologi'. Arabiyatuna: Jurnal Babasa Arab 1, no. 2 (2017): 139. https://doi.org/10.29240/jba.v1i2.286.

Jatiyasa, I Wayan. 'Pengajaran Keterampilan Menyimak Di Sekolah Dasar'. Lampubyang 3, no. 2 (2012): 57-67.

Khalilullah, M. 'Strategi Pembelajaran Bahasa Arab Aktif (Kemahiran Istima' Dan Takallum)'. Jurnal Sosial Budaya 8, no. 02 (2011): 219-35.

Kutlu, Ömer, and Aslihan Erman Aslanoğlu. 'Factors Affecting the Listening Skill'. Procedia - Social and Behavioral Sciences 1, no. 1 (2009): 2013-22. https://doi.org/10.1016/j.sbspro.2009.01.354.

Mahnun, Nunu. 'Media Pembelajaran (Kajian Terhadap Langkah-Langkah Pemilihan Media Dan Implementasinya Dalam Pembelajaran)'. An-Nida' 37, no. 1 (2012): 27-35.

Masqon, Dihyatun. 'Al-Lughah al-'Arabiyyah: Ta'limuha Wa Ta'alumuha Fi Indonesia al-Haditsah (Qira'ah Waqi'iyyah Namudzjiatan)'. TSAQAFAH 8, no. 1 (2012): 211-30.

Miles, Matthew B, and A Michael Huberman. Analisis Data Kualitatif: Buku Sumber Tentang Metode-Metode Baru. Terj. Tjet. Jakarta: Penerbit Universitas Indonesia, 1992. 
Mufidah, Nuril, Irtahat Isyaty, Nur Kholis, and Saidna Zulfiqar bin Tahir. 'ICT For Arabic Learning: A Blended Learning in Istima' II'. LISANUNA 8, no. 2 (2018): 174-83.

Mufidah, Nuril, and Intan Izha Rohima. 'Pengajaran Kosa Kata Untuk Mahasiswa Kelas Intensif Bahasa Arab'. Uniqbu Journal of Social Sciences (UJSS) 1, no. 1 (2020): 13-24.

Mustofa, Muhammad Arif. 'Analisis Penggunaan WhatsApp Sebagai Media Pembelajaran Bahasa Arab Di Era Industri 4.0'. Arabiyatuna: Jurnal Bahasa Arab 4, no. 2 (2020): 333. https://doi.org/10.29240/jba.v4i2.1805.

Nashoih, Afif Kholisun, and M. Faridl Darmawan. 'Pengembangan Bahan Ajar Nahwu Berbasis Kontrastif Untuk Mengatasi Interferensi Bahasa Indonesia Terhadap Bahasa Arab'. Arabiyatuna: Jurnal Babasa Arab 3, no. 2 (2019): 335-54. https://doi.org/10.29240/jba.v3i2.1008.

Ngalimun, and $\mathrm{N}$ Alfulaila. Pembelajaran Keterampilan Berbahasa Indonesia. Yogyakarta: Aswaja Pressindo, 2014.

Nugrawiyati, Jepri. 'MEDIA AUDIO-VISUAL DALAM PEMBELAJARAN BAHASA ARAB Pendahuluan Definisi Media Pembelajaran'. ElWasathiya: Jurnal Studi Agama 6, no. 1 (2018): 97-111.

Nunan, D. 'Designing and Adapting Materials to Encourage Learner Autonomy'. In Autonomy and Independence in Language Learning, edited by $\mathrm{P}$ Benson and P Voller. London: Longman, 1997.

Oensyar, Kamil Ramma, and Ahmad Hifni. METODOLOGI PEMBELAJARAN BAHASA ARAB. Banjarmasin: IAIN Antasari Press, 2015.

Richards, Jack C. Teaching Listening and Speaking From Theory to Practice. Cambridge: Cambridge University Press, 2008.

Rini, Rini, and Renti Yasmar. 'Peningkatan Kompetensi Istima' Wa Takallum Melalui Media Film'. Arabiyatuna: Jurnal Bahasa Arab 4, no. 1 (2020): 155. https://doi.org/10.29240/jba.v4i1.1384.

Rosyidi, Abd Wahab, and Mamlu'atul Ni'mah. Memahami Konsep Dasar Pembelajaran Bahasa Arab, 2011.

Safitri, Yusmaniar, Nurzaman Nurzaman, and Tatang Tatang. 'Hubungan Antara Keterampilan Menyimak Dengan Kemampuan Menulis Karangan Bahasa Arab'. Antologi.Upi.Edu, 2014, 1-9. 
Sirajudeen, Adam, and Abdul Wahid Adebisi. 'Teaching Arabic as a Second Language in Nigeria'. Procedia - Social and Behavioral Sciences 66 (2012): 126-35. https://doi.org/10.1016/j.sbspro.2012.11.254.

Soedjiatno, Soedjiatno. Perkembangan Bahasa Jawa Sesudah Perang Dunia Kedua. Jakarta: Pusat Pembinaan dan Pengembangan Bahasa, Departemen Pendidikan dan Kebudayaan, 1984.

Solak, Ekrem, and Gamze Erdem. Teaching Language Skills for Prospective English Teachers. Edited by Ekrem Solak. Ankara, 2016.

Tarigan, Henry Guntur. Menyimak Sebagai Suatu Keterampilan Berbabasa. Bandung: Angkasa, 2008.

Wahab, Muhbib Abdul. 'Tantangan Dan Prospek Pendidikan Bahasa Arab Di Indonesia'. Afaq Arabiyyah 2, no. 1 (2007): 1-18.

Wekke, Ismail Suardi. 'Arabic Teaching and Learning: A Model from Indonesian Muslim Minority'. Procedia - Social and Behavioral Sciences 191 (2015): 286-90. https://doi.org/10.1016/j.sbspro.2015.04.236.

Yahya, Yuangga Kurnia. 'Pengaruh Penyebaran Islam Di Timur Tengah Dan Afrika Utara: Studi Geobudaya Dan Geopolitik'. Al-Tsaqafa: Jurnal Peradaban Islam 16, no. 1 (2019): 44-62.

Yahya, Yuangga Kurnia, Umi Mahmudah, and Luthfi Muhyiddin. 'De-Sakralisasi Dalam Pembelajaran Bahasa Arab Di Indonesia: Analisis Bahasa Sebagai Identitas Agama'. Jurnal Lingua Applicata 3, no. 2 (2020): 57-70.

Yllmaz, Hande, and Fatih Yavuz. 'The Problems Young Learners Encounter During Listening Skills'. Procedia - Social and Behavioral Sciences 197, no. February (2015): 2046-50. https://doi.org/10.1016/j.sbspro.2015.07.570. 